\title{
Effects of Different Types of Fibers on the Physical and Mechanical Properties of MICP-Treated Calcareous Sand
}

\author{
Jitong Zhao ${ }^{1}$, Huawei Tong ${ }^{1}$, Yi Shan ${ }^{1}{ }^{\oplus}$, Jie Yuan ${ }^{1, *}$, Qiuwang Peng ${ }^{2}$ and Junling Liang ${ }^{1}$ \\ 1 School of Civil Engineering, Guangzhou University, Guangzhou 510006, China; \\ 2111816008@e.gzhu.edu.cn (J.Z.); tonghw@gzhu.edu.cn (H.T.); yshan@gzhu.edu.cn (Y.S.); \\ 2111916143@e.gzhu.edu.cn (J.L.) \\ 2 Foshan Railway Investment Construction Group Co., Ltd., Foshan 528000, China; pengqiuwang@fmetro.net \\ * Correspondence: yuanj@gzhu.edu.cn
}

Citation: Zhao, J.; Tong, H.; Shan, Y.; Yuan, J.; Peng, Q.; Liang, J. Effects of Different Types of Fibers on the Physical and Mechanical Properties of MICP-Treated Calcareous Sand. Materials 2021, 14, 268. https:// doi.org/10.3390/ma14020268

Received: 16 November 2020 Accepted: 4 January 2021 Published: 7 January 2021

Publisher's Note: MDPI stays neutral with regard to jurisdictional clai$\mathrm{ms}$ in published maps and institutional affiliations.

Copyright: (C) 2021 by the authors. Licensee MDPI, Basel, Switzerland. This article is an open access article distributed under the terms and conditions of the Creative Commons Attribution (CC BY) license (https:// creativecommons.org/licenses/by/ $4.0 /)$.

\begin{abstract}
Microbial-induced calcite precipitation (MICP) has been a promising method to improve geotechnical engineering properties through the precipitation of calcium carbonate $\left(\mathrm{CaCO}_{3}\right)$ on the contact and surface of soil particles in recent years. In the present experiment, water absorption and unconfined compressive strength (UCS) tests were carried out to investigate the effects of three different fiber types (glass fiber, polyester fiber, and hemp fiber) on the physical and mechanical properties of MICP-treated calcareous sand. The fibers used were at $0 \%, 0.10 \%, 0.15 \%, 0.20 \%, 0.25 \%$, $0.30 \%, 0.35 \%$, and $0.40 \%$ relative to the weight of the sand. The results showed that the failure strain and ductility of the samples could be improved by adding fibers. Compared to biocemented sand (BS), the water absorption of these three fiber-reinforced biocemented sands were, respectively, decreased by $11.60 \%, 21.18 \%$, and $7.29 \%$. UCS was, respectively, increased by $24.20 \%, 60.76 \%$, and $6.40 \%$. Polyester fiber produced the best effect, followed by glass fiber and hemp fiber. The optimum contents of glass fiber and polyester fiber were $0.20 \%$ and $0.25 \%$, respectively. The optimum content of hemp fiber was within the range of $0.20-0.25 \%$. Light-emitting diode (LED) microscope and scanning electron microscope (SEM) images lead to the conclusion that only a little calcite precipitation had occurred around the hemp fiber, leading to a poor bonding effect compared to the glass and polyester fibers. It was therefore suggested that polyester fiber should be used to improve the properties of biocemented sand.
\end{abstract}

Keywords: microbial-induced calcite precipitation (MICP); water absorption; unconfined compressive strength (UCS); glass, polyester, and hemp fibers; bonding effect

\section{Introduction}

Calcareous sand is the main foundation soil in the South China Sea. It is a type of special rock and soil medium with irregular shapes, many internal pores, low loadbearing capacity, and ready susceptibility to particle breakage under pressure [1]. This soil foundation is easily prone to destruction due to insufficient tolerance capacity under the action of periodic load [2]. Therefore, it requires foundation treatment to improve the physical and mechanical properties of the calcareous sand area [3].

A new soil reinforcement technology has been found to improve the physical and mechanical properties of calcareous sand, known as microbial-induced calcite precipitation (MICP) [4,5]. It was first proposed by Australian geological engineer Whiffin [6]. The MICP treatment method has gained interest due to its relatively environmentally friendly characteristics, low energy consumption, and sustainable advantages [7]. Many recent studies have shown that the MICP treatment technique could effectively improve strength and stiffness [8-12]; decrease permeability [13-16]; increase resistance to liquefaction [17-19]; and enhance concrete self-healing [20-22]. All the above studies indicated that as a new technology for foundation reinforcement, MICP could effectively improve 
stiffness, strength, and permeability. It was also found to offer a potential value when applied to improve liquefaction and concrete self-healing.

A few studies among those related to improving sand by MICP treatment investigated reinforced sand ductility by adding fibers [23-26]. Among these, Choi [24] mixed Ottawa 20-30 sand and polyvinyl acetate (PVA) fibers in five different fiber proportions, and found that the splitting tensile strength and splitting secant elastic modulus increased when the ratio of either calcium carbonate or fiber content was augmented. Xiao [25] obtained unconfined compressive strength (UCS), splitting tensile strength (STS), and peak failure state strain increases by increasing fiber content relative to a given calcite content. This was interpreted to be due to the interlocking, reinforcing, and bonding effects observed in SEM images.

However, the above studies were all based on the effect of adding a single type of fiber into the biocement material. The present experiment aimed to fully understand the effects of different fiber types on the physical and mechanical properties of MICP-treated calcareous sand. According to different sources, fibers can be roughly divided into natural, synthetic, and inorganic fibers in nature. Inorganic fiber refers to a chemical fiber made by a chemical reaction with minerals as a raw material. Its difference from synthetic fiber is based on the different sources of raw materials. Common inorganic fibers mainly include glass fiber, ceramic fiber, metal fiber, carbon fiber, etc. Synthetic fiber, also known as chemical fiber, refers to the polymer produced by a chemical reaction to form a polymer. There are various types of synthetic fiber, which often show different physical and chemical properties due to the different raw materials of the polymer. Natural fibers refer to the fibers on plants and animals that are naturally generated in nature. According to the sources of natural fibers, they can be divided into two categories: plant fibers and animal fibers. As a kind of fiber that widely exists in nature, they are widely used in various industries because of their low cost, easy access, and high yield. In this paper, we selected three fiber types commonly used in previous fiber-reinforced soil studies: glass fiber [27-29], polyester fiber [30,31], and hemp fiber [32,33]. For this purpose, a series of water absorption and unconfined compressive strength (UCS) tests were carried out to investigate the effects of these three different types of fibers. This study aims at providing a theoretical basis for the selection of fibers for field MICP-treated sand.

\section{Materials and Methods}

\subsection{Materials}

\subsubsection{Bacterial Culture and Cementation Solution}

A sterilized liquid medium consisting of $20 \mathrm{~g} / \mathrm{L}$ yeast extract, $10 \mathrm{~g} / \mathrm{L}\left(\mathrm{NH}_{4}\right)_{2} \mathrm{SO}_{4}$, and $1.6 \mathrm{~g} / \mathrm{L} \mathrm{NaOH}$ (Xilong Scientific Co., Ltd., Shantou, China) with a $\mathrm{pH}$ of 9.0 was used for the bacterial (Sporosarcina pasteurii, GDMCC China) fermentation. The bacteria were cultured in a conical flask at $200 \mathrm{rpm}$ and $28^{\circ} \mathrm{C}$ for $36 \mathrm{~h}$. The bacteria had an optical density of 1.0 to 1.8. The urease activity of the bacteria was measured by way of conductivitymeasuring medium, and was approximately $4.75 \mathrm{mM}$ urea/min. The cementation solution was composed of $0.5 \mathrm{~mol} / \mathrm{L} \mathrm{CaCl}_{2}$ and $0.5 \mathrm{~mol} / \mathrm{L}$ urea [34].

\subsubsection{Characteristics of Calcareous Sand}

Calcareous sand from Yongxing Islands located in the South China Sea was chosen for the tests. Its physical and mechanical parameters are shown in Table 1 below. Before the test, the sand was placed in an oven for drying at $40^{\circ} \mathrm{C}$ for $24 \mathrm{~h}$. The grading curve of calcareous sand is shown in Figure 1 below. The grain size of the sand ranged from 0.2 to $1 \mathrm{~mm}$, which was classed as fine sand with uniform sand particles and poor grading. 
Table 1. Physical and mechanical parameters of calcareous sand.

\begin{tabular}{cc}
\hline Property & Value \\
\hline Specific gravity $\mathrm{G}_{\mathrm{s}}$ & 2.76 \\
Maximum dry density $\rho_{\max }\left(\mathrm{g} / \mathrm{cm}^{3}\right)$ & 1.524 \\
Minimum dry density $\rho_{\min }\left(\mathrm{g} / \mathrm{cm}^{3}\right)$ & 1.230 \\
$\mathrm{~d}_{10}(\mathrm{~mm})$ & 0.26 \\
$\mathrm{~d}_{30}(\mathrm{~mm})$ & 0.42 \\
$\mathrm{~d}_{60}(\mathrm{~mm})$ & 0.58 \\
Uniformity coefficient $\mathrm{C}_{\mathrm{u}}$ & 2.231 \\
Coefficient of curvature $\mathrm{C}_{\mathrm{c}}$ & 1.170 \\
\hline
\end{tabular}

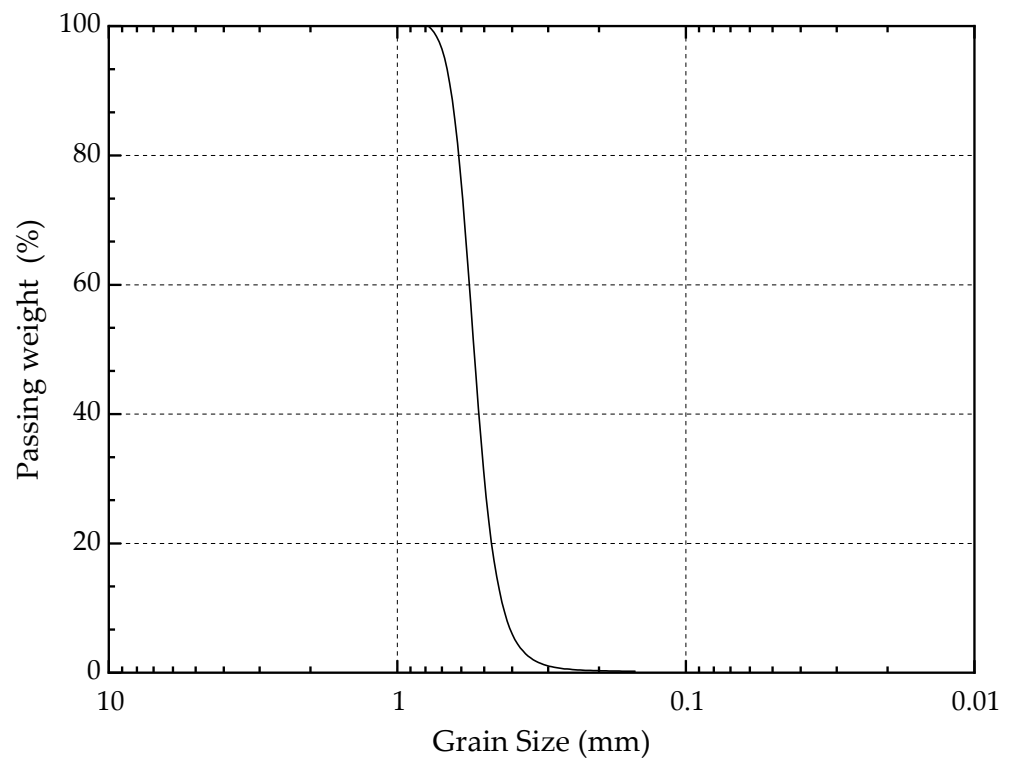

Figure 1. Grain size distribution of the calcareous sand.

\subsubsection{Fiber Types}

In the experiments, glass fiber, polyester fiber, and hemp fiber were selected. Silicon dioxide $\left(\mathrm{SiO}_{2}\right)$ dominates the chemical composition of glass fiber, giving the glass fiber better resistance to wear and corrosion [35]. The polyester fibers had a special trilobal cross-section which offers better surface roughness than the conventional circular crosssection [30]. Hemp fiber belongs to the natural plant fiber category, which is more widely distributed and easier to obtain than animal fibers. The physical and mechanical properties of these three different fiber types used in the experiments are shown in Table 2 below; the morphology of these three fibers is shown in Figure 2 below.

Table 2. Physical and chemical properties of the fibers.

\begin{tabular}{cccccccc}
\hline Fiber Types & Color & $\begin{array}{c}\text { Length } \\
(\mathbf{m m})\end{array}$ & $\begin{array}{c}\text { Tensile Strength } \\
\mathbf{( M P a )}\end{array}$ & $\begin{array}{c}\text { Density } \\
\mathbf{( g / \mathbf { c m } ^ { 3 } )}\end{array}$ & $\begin{array}{c}\text { Modulus of } \\
\text { Elasticity (GPa) }\end{array}$ & $\begin{array}{c}\text { Fusion Point } \\
\left({ }^{\circ} \mathbf{C}\right)\end{array}$ & $\begin{array}{c}\text { Elongation } \\
(\mathbf{\%})\end{array}$ \\
\hline Glass fiber & White & 6 & 346 & 0.91 & 4.286 & 169 & 36.4 \\
Polyester fiber & White & 6 & 550 & 1.36 & 13.500 & 259 & 13.8 \\
Hemp fiber & Yellow & 6 & 255 & 1.12 & 5.369 & 189 & 26.6 \\
\hline
\end{tabular}




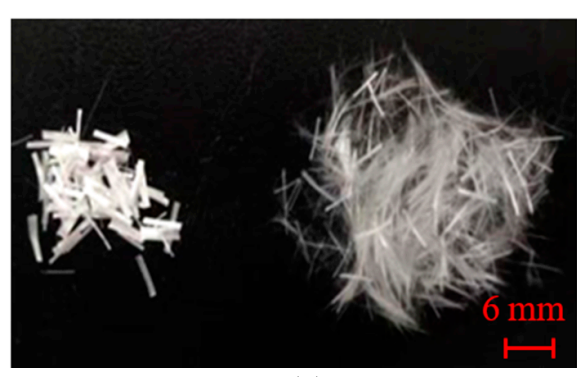

(a)

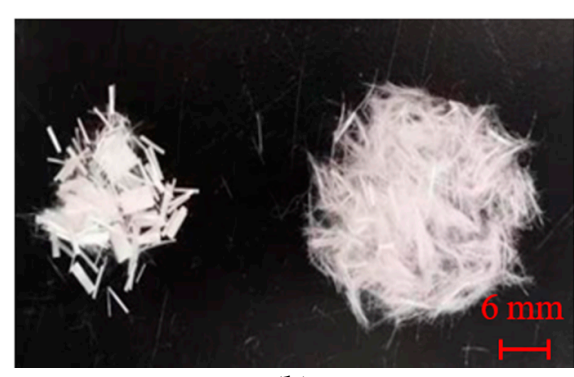

(b)

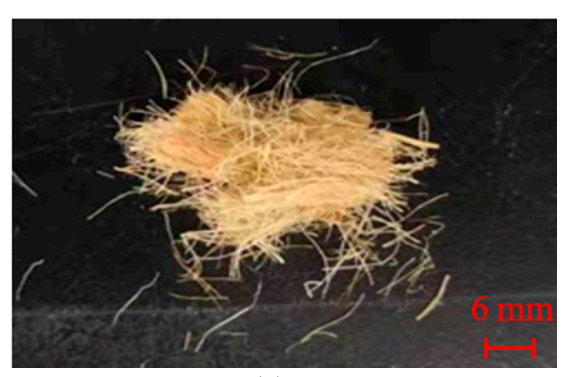

(c)

Figure 2. Morphology of the fibers: (a) Glass fiber; (b) Polyester fiber; (c) Hemp fiber.

\subsection{Specimen Preparation}

\subsubsection{The Clean and Fiber-Reinforced Sand}

Cylindrical specimens with a diameter of $39.1 \mathrm{~mm}$ and a height of $80 \mathrm{~mm}$ were used for the water absorption and unconfined compressive strength tests. The relative density of the sample was controlled at $50 \%$ (130.67 g of calcareous sand) [36]. The three different fibers at $0.1 \%, 0.15 \%, 0.2 \%, 0.25 \%, 0.3 \%, 0.35 \%$, and $0.4 \%$ (by weight of sand, respectively) were added. Furthermore, a control group without any fiber was set up. Eight percent of distilled water (by weight) was added to the sand and easily mixed uniformly with the fiber within the sand column. After uniform stirring, the specimens were divided into three layers into the mold. Each layer was slightly compacted with a compaction tool.

\subsubsection{Grouting Procedure}

Based on the study of Xiao [19] and our instrument requirements, a peristaltic pump was used in the experiments to reinforce samples with cycled grouting. The grouting reinforcement procedure is shown in Figure 3 below.

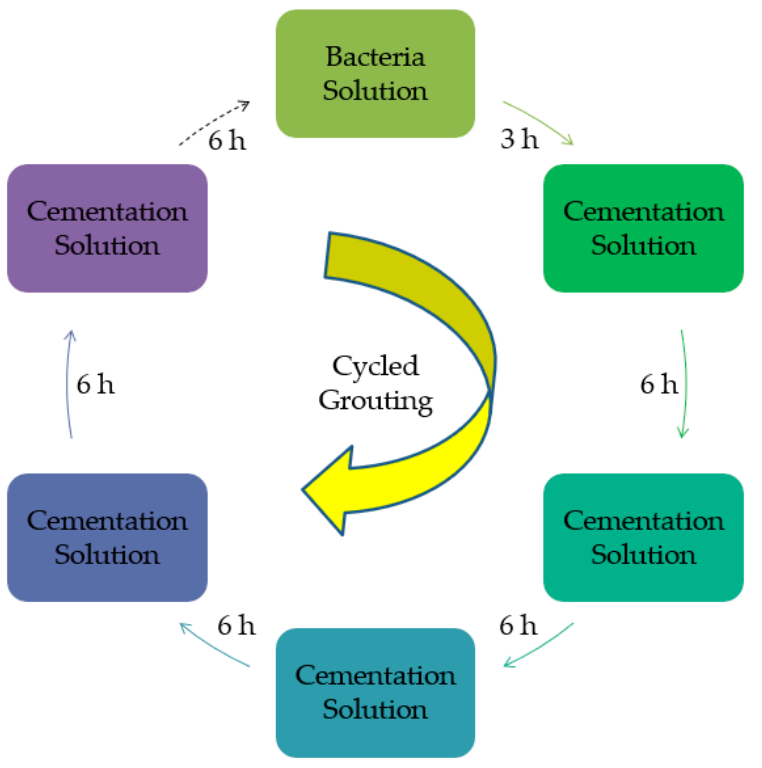

Figure 3. Grouting procedure.

The grouting rate was set at $1.5 \mathrm{~mL} / \mathrm{min}$. A total of 4 rounds of grouting were carried out, and each injection volume was one specimen pore volume (i.e., $50 \mathrm{~mL}$ ). The specimens were prepared at a room temperature of approximately $25^{\circ} \mathrm{C}$ [37]. The schematic diagram of the grouting procedure is shown in Figure 4 below. A photograph of the grouting is shown in Figure 5 below. 


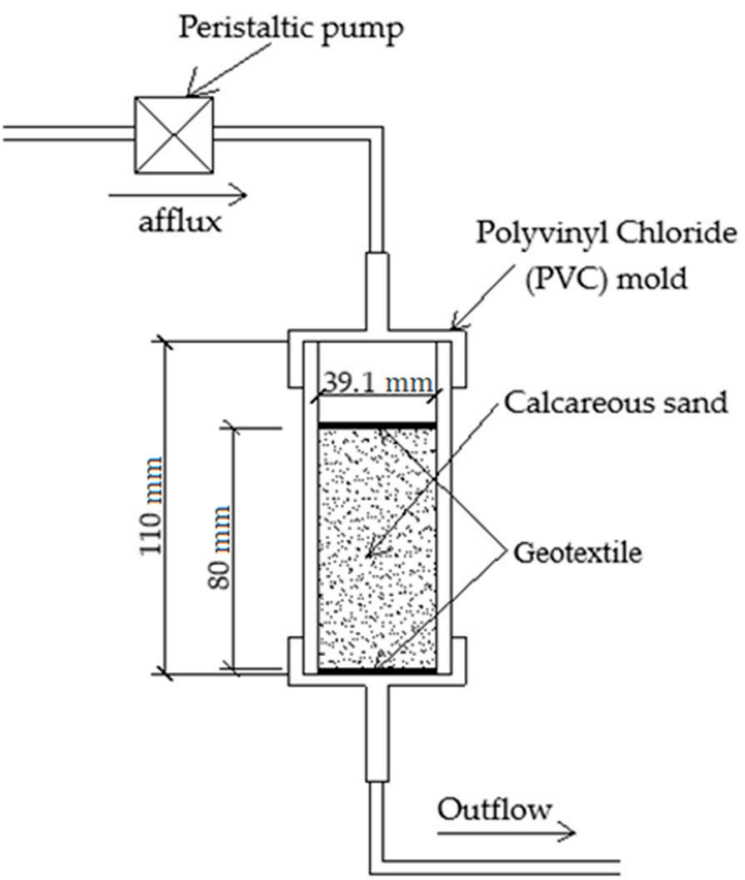

Figure 4. Schematic diagram of the grouting procedure.

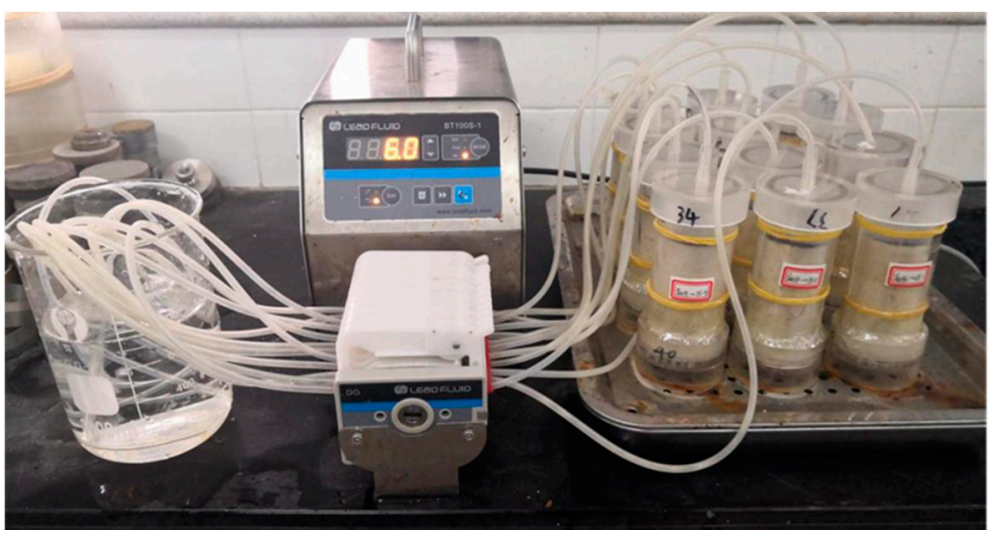

Figure 5. Grouting procedure of the peristaltic pump.

\subsection{Testing Method}

\subsubsection{Water Absorption Test}

The water absorption represented the water absorption capacity under standard atmospheric pressure of the specimen after grouting. It also reflected the quantity of surface pores of the specimen. Therefore, the water absorption capacity of biocemented sand was studied using the water absorption test. Based on Manzur's research [38], the water absorption capacity of the biocemented sand was tested. The test steps were as follows: the MICP-treated specimens were dried in an oven (Yicheng Instrument Manufacturing Co. Ltd., Shaoxing, China) at $108{ }^{\circ} \mathrm{C}$, and the dry mass $\mathrm{m}_{1}$ was recorded. Then, the specimen was dipped to a depth of 5-10 mm in distilled water for $24 \mathrm{~h}$ and removed from the sand column. Excess water was blotted off, and the new mass $m_{2}$ was recorded. Lastly, the water absorption of the specimen $\omega$ was calculated according to Equation (1):

$$
\omega=\frac{m_{2}-m_{1}}{m_{1}} \times 100 \%
$$




\subsubsection{Unconfined Compressive Strength Test}

A series of unconfined compressive tests was performed to measure the unconfined compressive strength (UCS) of the specimens after grouting. The specimens used in the UCS test were dried in an oven at $108{ }^{\circ} \mathrm{C}$. The instrument used for the test was a YAWS300 automatic liquid crystal pressure testing machine. A loading rate of $1 \mathrm{~mm} / \mathrm{min}$ was adopted. Table 3 below lists the detailed test results of 22 specimens with different fiber types and contents.

Table 3. Test results of the biocemented sands with different fiber types and contents.

\begin{tabular}{|c|c|c|c|c|c|c|c|c|}
\hline Group & Test No. & $\begin{array}{c}\text { Fiber Content } \\
(\%)\end{array}$ & $D_{r}{ }^{a}(\%)$ & $\Delta \mathrm{m}^{\mathrm{b}}(\mathrm{g})$ & $\begin{array}{c}\rho_{d}^{c} \\
\left(g / \mathrm{cm}^{3}\right)\end{array}$ & $\omega^{d}(\%)$ & $\begin{array}{l}\text { UCS e } \\
(\mathrm{MPa})\end{array}$ & $\begin{array}{c}\text { Modulus of } \\
\text { Elasticity (MPa) }\end{array}$ \\
\hline $\begin{array}{l}\text { Biocemented } \\
\text { sand (BS) }\end{array}$ & BS & 0 & 48 & 24.86 & 1.676 & 21.81 & 1.343 & 59.848 \\
\hline \multirow{7}{*}{$\begin{array}{c}\text { Glass fiber } \\
\text { biocemented } \\
\text { sand (GF-BS) }\end{array}$} & GF-BS-1 & 0.10 & 49 & 25.14 & 1.689 & 20.15 & 1.329 & 64.577 \\
\hline & GF-BS-2 & 0.15 & 50 & 26.73 & 1.706 & 19.99 & 1.448 & 50.121 \\
\hline & GF-BS-3 & 0.20 & 49 & 26.04 & 1.737 & 19.28 & 1.668 & 58.940 \\
\hline & GF-BS-4 & 0.25 & 48 & 24.58 & 1.684 & 22.11 & 1.593 & 61.553 \\
\hline & GF-BS-5 & 0.30 & 49 & 24.77 & 1.676 & 22.68 & 1.464 & 63.076 \\
\hline & GF-BS-6 & 0.35 & 49 & 24.02 & 1.654 & 22.62 & 1.253 & 56.929 \\
\hline & GF-BS-7 & 0.40 & 50 & 24.12 & 1.612 & 23.73 & 1.223 & 62.176 \\
\hline \multirow{7}{*}{$\begin{array}{c}\text { Polyester fiber } \\
\text { biocemented } \\
\text { sand (PF-BS) }\end{array}$} & PF-BS-1 & 0.10 & 49 & 26.33 & 1.707 & 21.37 & 1.502 & 66.080 \\
\hline & PF-BS-2 & 0.15 & 48 & 27.14 & 1.711 & 21.10 & 1.547 & 64.566 \\
\hline & PF-BS-3 & 0.20 & 50 & 27.31 & 1.724 & 18.67 & 1.729 & 64.732 \\
\hline & PF-BS-4 & 0.25 & 49 & 28.48 & 1.839 & 17.19 & 2.159 & 60.544 \\
\hline & PF-BS-5 & 0.30 & 50 & 25.42 & 1.742 & 20.58 & 1.645 & 66.626 \\
\hline & PF-BS-6 & 0.35 & 48 & 25.04 & 1.701 & 21.42 & 1.329 & 64.421 \\
\hline & PF-BS-7 & 0.40 & 49 & 25.26 & 1.707 & 21.23 & 1.184 & 63.147 \\
\hline \multirow{7}{*}{$\begin{array}{l}\text { Hemp fiber } \\
\text { biocemented } \\
\text { sand (HF-BS) }\end{array}$} & HF-BS-1 & 0.10 & 49 & 23.32 & 1.641 & 22.09 & 0.944 & 49.710 \\
\hline & HF-BS-2 & 0.15 & 50 & 23.97 & 1.649 & 22.27 & 0.980 & 54.657 \\
\hline & HF-BS-3 & 0.20 & 48 & 23.87 & 1.705 & 20.22 & 1.271 & 56.289 \\
\hline & HF-BS-4 & 0.25 & 49 & 25.84 & 1.657 & 22.01 & 1.429 & 60.397 \\
\hline & HF-BS-5 & 0.30 & 50 & 24.05 & 1.673 & 21.95 & 1.152 & 60.663 \\
\hline & HF-BS-6 & 0.35 & 50 & 24.36 & 1.640 & 22.51 & 0.975 & 63.976 \\
\hline & HF-BS-7 & 0.40 & 49 & 23.60 & 1.580 & 23.51 & 0.935 & 56.804 \\
\hline
\end{tabular}

Note: a. Relative density $\left(D_{\mathrm{r}}=\frac{\left(\rho_{\mathrm{d}}{ }^{\prime}-\rho_{\mathrm{dmin}}\right) \rho_{\mathrm{dmax}}}{\left(\rho_{\mathrm{dmax}}-\rho_{\mathrm{dmin}}\right) \rho_{\mathrm{d}}{ }^{\prime}}\right.$ (where $\rho_{\mathrm{d}}{ }^{\prime}$ is the dry density before grouting, $\rho_{\mathrm{dmax}}$ is the maximum dry density before grouting, $\rho_{\mathrm{dmin}}$ is the minimum dry density before grouting); b. Calcium carbonate precipitation of the specimens $\left(\Delta \mathrm{m}=\mathrm{m}_{\mathrm{a}}-\mathrm{m}_{\mathrm{b}}\right.$ where $\mathrm{m}_{\mathrm{a}}$ is the dry mass after grouting, $\mathrm{m}_{\mathrm{b}}$ is the dry mass before grouting); c. Dry density after MICP treatment $\left(\rho_{\mathrm{d}}=\frac{\mathrm{m}_{\mathrm{a}}}{\mathrm{V}}\right.$ where V is the volume of the cylinder sample); d. Water absorption of the specimens after grouting, as shown in Section 2.3.1. e. Unconfined Compressive Strength.

\section{Results}

\subsection{Water Absorption Test Results}

The effects of water absorption by the specimens are given in Figure 6 below. For all fiber types, water absorption decreased with increased fiber content. This trend continued up to a certain fiber content, beyond which water absorption increased. The minimum values of water absorption by the glass fiber biocemented sand (GF-BS), polyester fiber biocemented sand (PF-BS), and hemp fiber biocemented sand (HF-BS) were obtained at $0.20 \%, 0.25 \%$, and $0.20 \%$ fiber content. This showed a reduction of $11.60 \%, 21.18 \%$, and $7.29 \%$, respectively, in water absorption over the BS control. The water absorption of the GF-BS was higher than the BS only under high fiber contents, while that of HF-BS essentially remained above the BS except for the $0.20 \%$ fiber content. When comparing the water absorption of three different fiber-reinforced biocemented sand samples, it was found that the water absorption of PF-BS was the lowest, followed by GF-BS and HF-BS. 


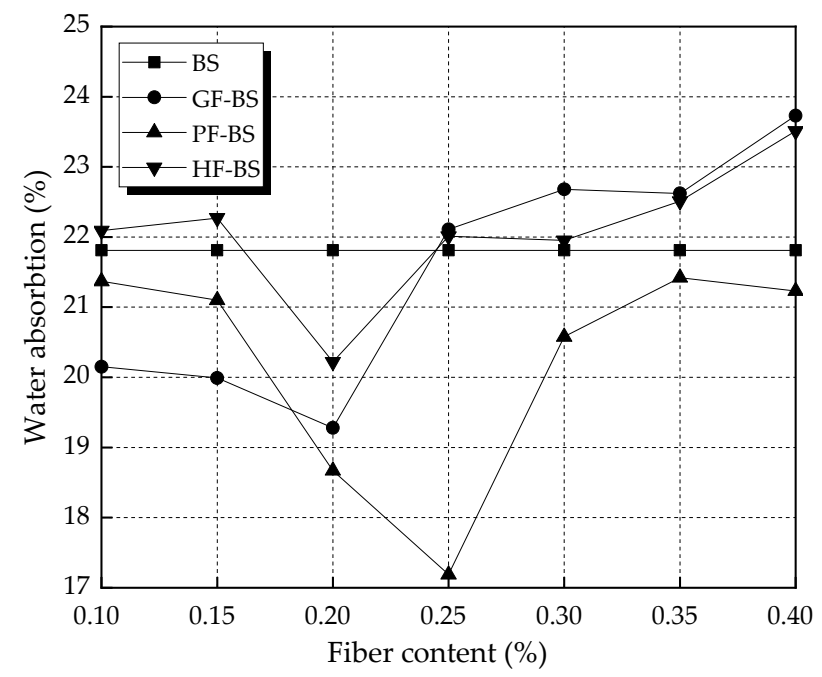

Figure 6. Water absorption of the specimens.

\subsection{Stress-Strain Curve of UCS Test Results}

The results of the stress-strain curve of three different fiber-reinforced biocemented sand samples are shown in Figure 7. With the vertical load, the stress increased with the rise in strain in the initial stage until the stress reached its peak. This was similar to the elastic deformation stage. The biocemented sands under different fiber types and contents showed similar behavior at the initial stage until the stress reached its peak. As the stress of the biocemented sands reached its peak value, the samples began to crack and become damaged. For the GF-BS, the stress and strain trend of the sample after failure was roughly consistent with that of the BS, as shown in Figure 7a below. It indicated that glass fiber was ineffective in improving the ductility of the sample. For the PF-BS, as shown in Figure $7 \mathrm{~b}$ below, at the low fiber content of $0.1 \%$ and $0.2 \%$, poor improvement in ductility of the samples was achieved. However, under other fiber contents, the stress-strain trend of samples after failure was slower than that of the BS. This indicated that when the polyester fiber content was $0.2 \%$ to $0.4 \%$, sample ductility could be increased. For the HF-BS, the ductility improvement of the sample was relatively poor: the decreasing trend of stress and strain became slow only when the stress value of the sample decreased to a low level, as shown in Figure 7c below. This indicated that the hemp fiber cannot play an immediate role when the sample is destroyed. In conclusion, polyester fiber had the best effect on the improved ductility of the biocemented sand.

\subsection{Unconfined Compressive Strength Test Results}

The results of unconfined compressive strength (UCS) tests of biocemented sands are given in Figure 8 below. For the fiber-reinforced biocemented sand, the UCS increased with the increase in fiber content. When the fiber content increased to a certain value, UCS decreased as the fiber content increased. The maximum UCS of the GF-BS, PF-BS, and HF-BS was obtained at $0.20 \%, 0.25 \%$, and $0.25 \%$ fiber content. The maximum strengths were $1.668 \mathrm{MPa}, 2.159 \mathrm{MPa}$, and $1.429 \mathrm{MPa}$, respectively. This showed an increase of $24.20 \%, 60.76 \%$, and $6.40 \%$ in strength, respectively, compared to the BS. The UCS of the GF-BS and HF-BS were lower than BS only under high contents. Comparing the UCS of three different fiber-reinforced biocemented sands led to the conclusion that the UCS of PF-BS was the highest. The UCS of GF-BS was the second highest, while the UCS of HF-BS was the lowest. On the basis of results from a comprehensive water absorption test, it was concluded that the optimum content of glass fiber and polyester fiber were $0.20 \%$ and $0.25 \%$, respectively. The optimum content of hemp fiber was shown to be within the range of $0.20-0.25 \%$. 


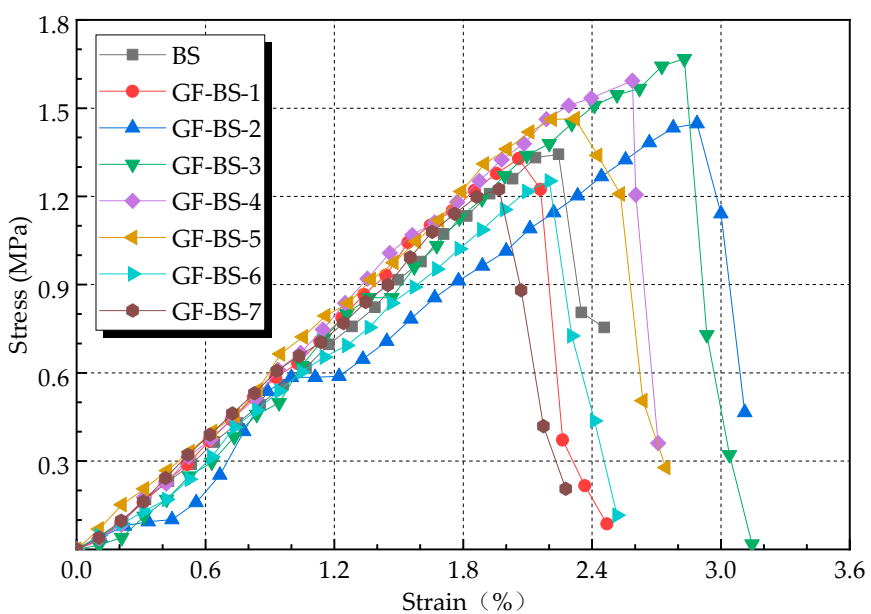

(a)

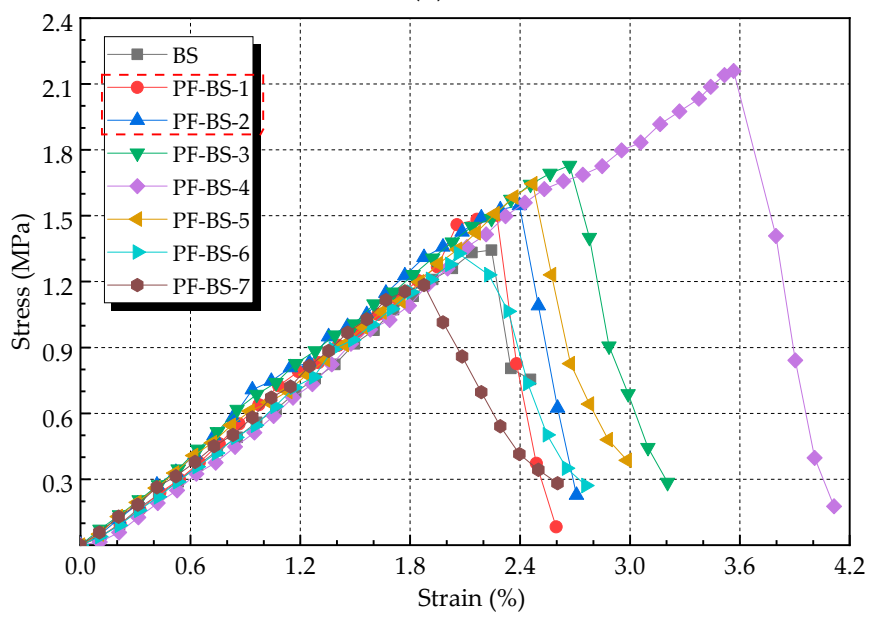

(b)

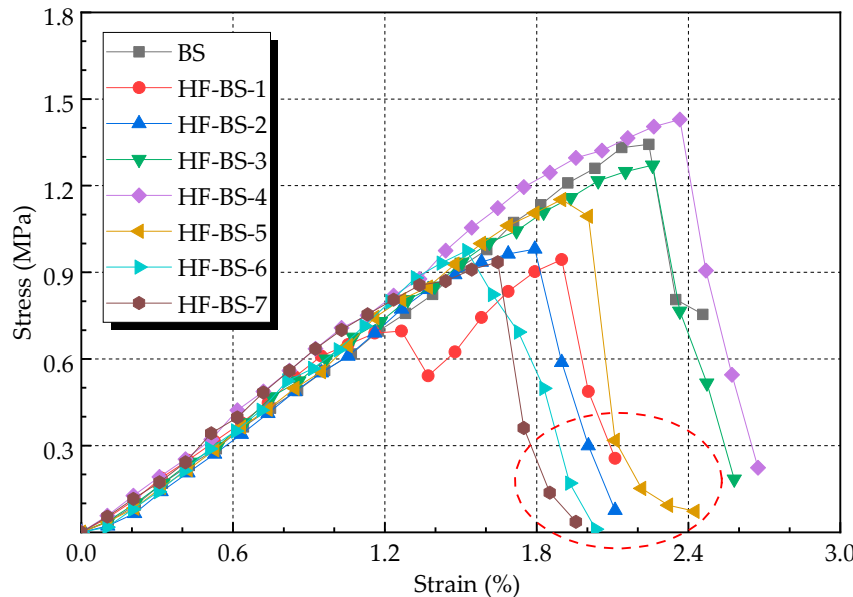

(c)

Figure 7. Stress-strain curves of reinforced sand under different fiber types and contents: (a) stressstrain curves of the GF-BS; (b) stress-strain curves of the PF-BS; (c) stress-strain curves of the HF-BS. 


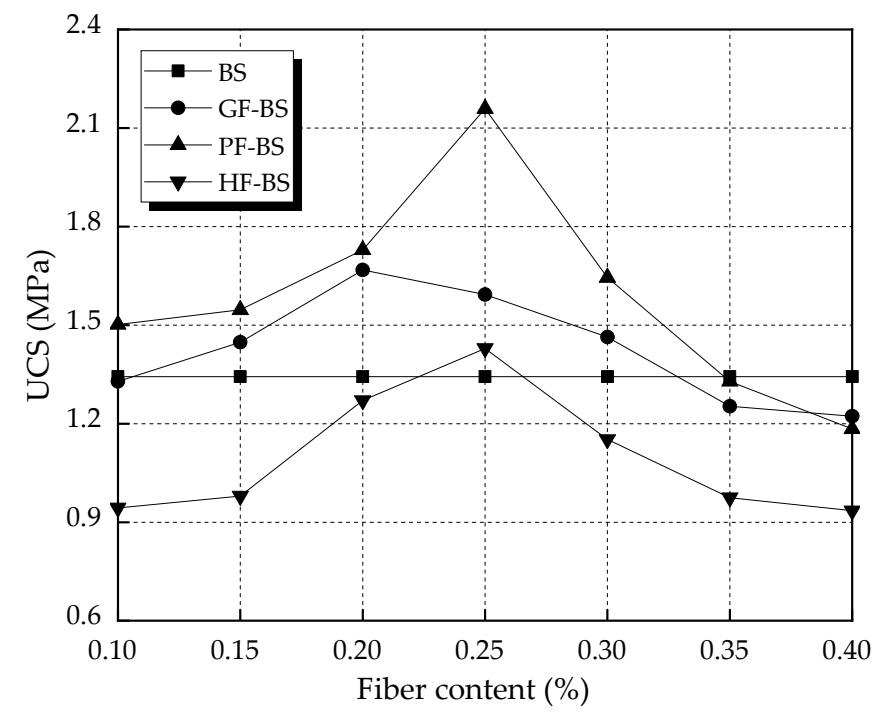

Figure 8. Unconfined compressive strength of biocemented sands.

\section{Discussion}

\subsection{UCS Versus Water Absorption}

Figure 9 below shows a UCS and water absorption diagram and includes the results of all biocemented sand tests. On the whole, it can be seen that with increased water absorption, the UCS of the sample decreased. This indicated that the pores on the surface of the sample were detrimentally impacting on the strength of the sample. The surface pores of the sample were determined by the location of calcium carbonate precipitation, which in turn depended on the path the solution flowed through during grouting. If the solutions could be made to flow into the sample more uniformly during grouting, the number of surface pores of the sample would be relatively reduced. This was beneficial to improve the strength of the sample.

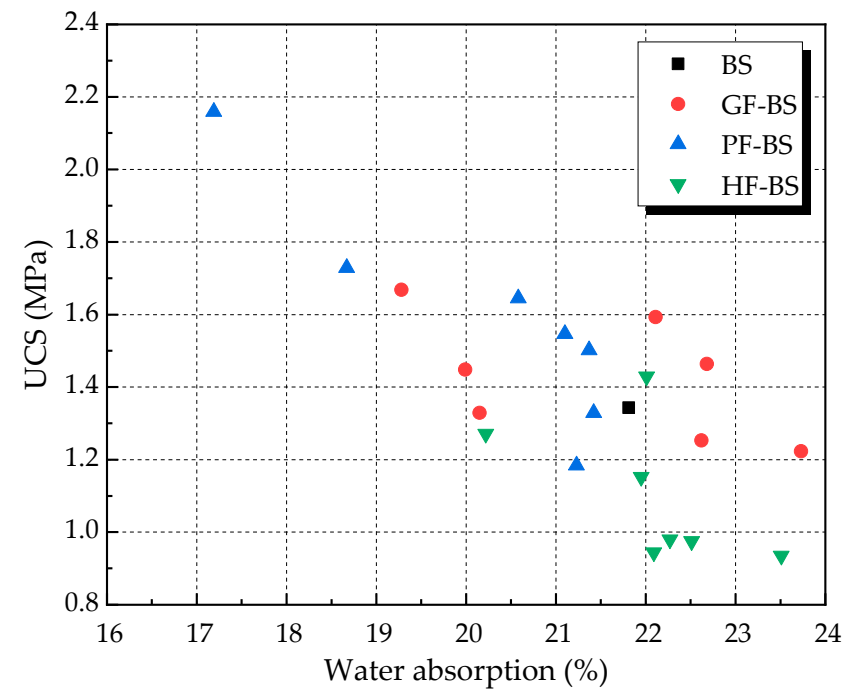

Figure 9. UCS and water absorption.

\subsection{The Modulus of Elasticity}

With vertical loading, stress increased at the initial stage alongside strain until the stress achieved its peak. This was similar to the elastic deformation stage. The biocemented sands under different fiber types and contents displayed the same behavior at the initial stage. Therefore, the stress-strain curve before peak stress was considered as a straight line. 
The modulus of elasticity of the sample was the slope of the line. The modulus of elasticity of all samples is shown in Table 3 below.

Figure 10 below shows the histogram obtained from the data in Table 3. As can be seen from Figure 10, the modulus of elasticity of PF-BS varies little under different fiber contents. GF-BS and HF-BS showed a general tendency to increase first and then decrease with the augmentation of fiber content. Comparing the three types of fiber-reinforced biocemented sands with different fiber contents, the modulus of elasticity of the PF-BS was higher than that of the other two types of fiber-reinforced biocemented sands. Both elastic moduli of PF-BS were higher than that of the BS. The modulus of elasticity of GF-BS was generally greater than that of HF-BS. The magnitude of the modulus of elasticity of all three types of fiber-reinforced biocemented sands was the same as that of unconfined compressive strength. This indicated that the stress of PF-BS was the highest under the same strain condition. In other words, the PF-BS achieved the greatest stiffness. The performance of the elastic modulus of PF-BS may have been due to its high calcium carbonate precipitation and the high tensile strength and modulus of elasticity of the polyester fiber. Therefore, the polyester fiber had the greatest effect on MICP-treated sands. The modulus of elasticity of the PF-BS was the highest, followed by the GF-BS and HF-BS.

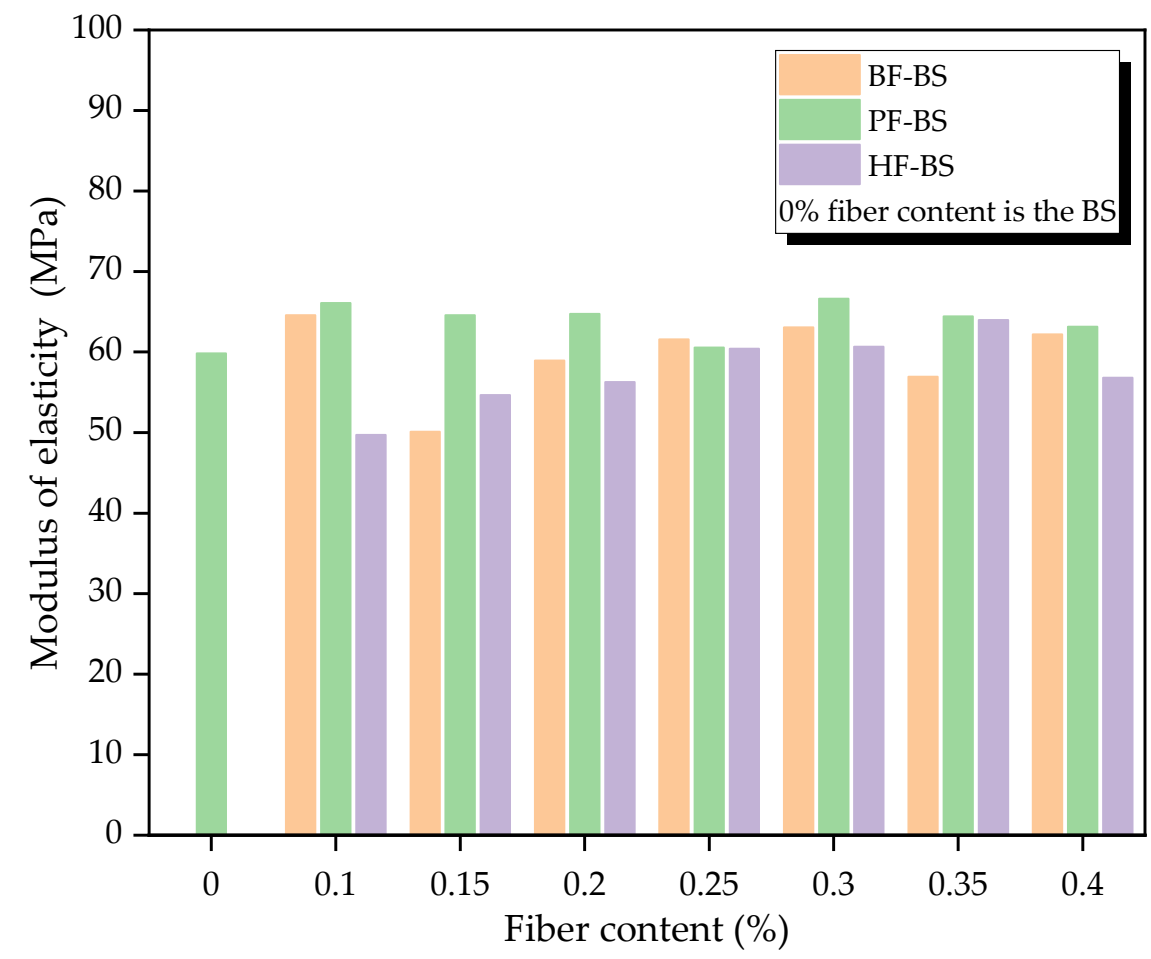

Figure 10. Modulus of elasticity of biocemented sand.

\subsection{Analysis of the Failure Pattern of Biocemented Sand}

The failure pattern of biocemented sand is shown in Figure 11 below. As shown in Figure 11 (BS), with the action of vertical pressure, sand particles at a certain position on the edge of the sample would begin to desquamate and gradually extend to the interior of the sample. The BS was eventually damaged by the partial failure. The samples under the different fiber types and contents were mainly damaged by shear failure (Figure 11 (HF-BS-4)) and splitting failure from top to bottom (Figure 11 (GF-BS-3), (PF-BS-4)). The reason was that when the weak connection in the sample approached breaking point, the fiber connection began to act across the fracture. The fiber connection across the fracture was found to have the ability to improve the partial strength of the sample. Moreover, this fiber connection provided the fiber-reinforced biocemented sand with a residual bearing capacity after cracking, thus the ductility of the sample was improved. 


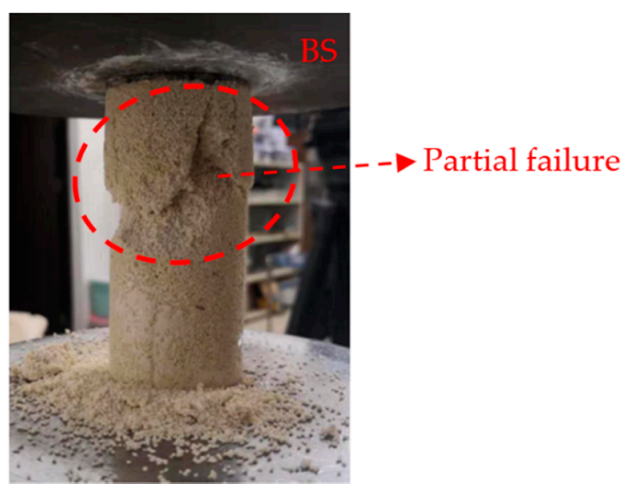

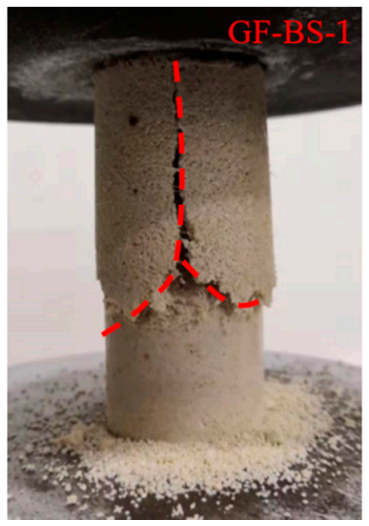
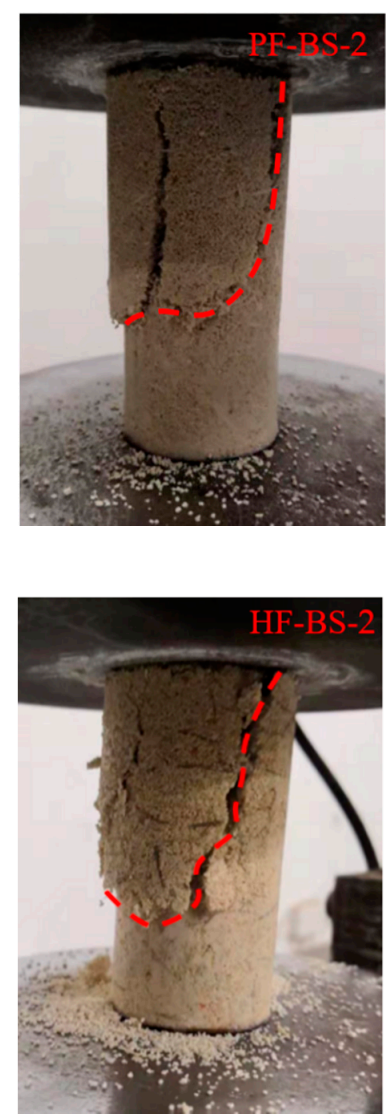

(a)

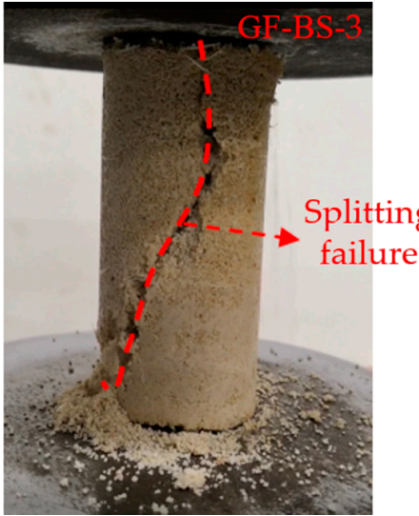

(b)

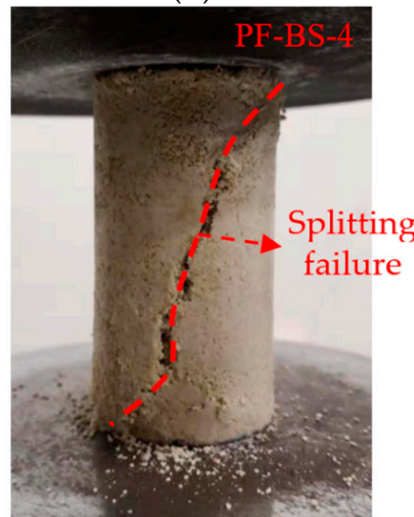

(c)

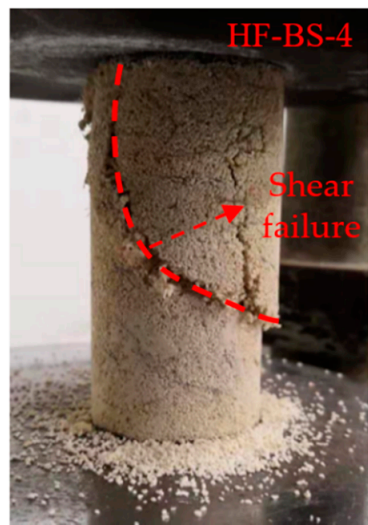

(d)
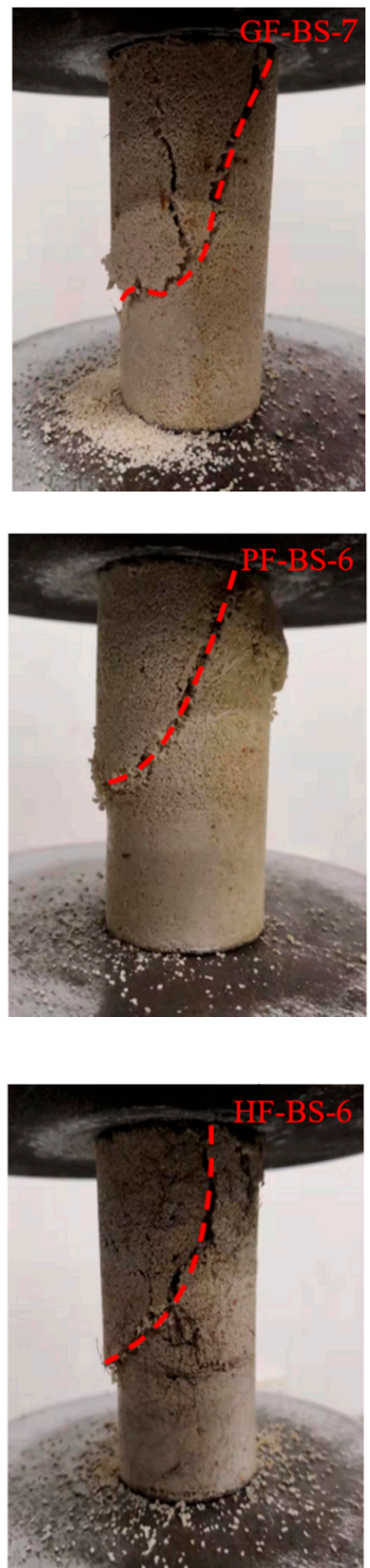

Figure 11. Failure pattern of biocemented sand under different fiber types and contents, (a) Failure pattern of the BS; (b) Failure pattern of biocemented sand under different glass fiber contents; (c) Failure pattern of biocemented sand under different polyester fiber contents; (d) Failure pattern of biocemented sand under different hemp fiber contents. 
The samples with glass fiber at a $0.20 \%$ content (Figure 11 (GF-BS-3)) and polyester fiber at a $0.25 \%$ content (Figure 11 (PF-BS-4)) were damaged by splitting failure. However, the sample mixed with hemp fiber at a $0.25 \%$ content (Figure 11 (HF-BS-4)) was damaged by shear failure at the top of the sample. This meant that the failure forms of the samples mixed with glass or polyester fiber were damaged by splitting failure at the maximum unconfined compressive strength, while the hemp fiber sample was damaged by shear failure. Moreover, the glass fiber and polyester fiber samples also incurred shear failure at low or high contents. This indicated that the glass fiber and polyester fiber samples provided greater improvement of the properties of the biocemented sand samples. Under high and low fiber contents, the failure type of the samples was changed from splitting failure to shear failure.

\subsection{Microscopic Analysis}

The specimens used for microscopic analysis were chosen from the samples with the highest UCS. As shown in Figure 12 below, specimens were obtained from the middle of the specimen and a position on the plane of fracture. Since the grouting was poured down from the top of the sample, this method was able to control the effects of the duration of the solution being poured through and the effect of the magnitude of UCS.

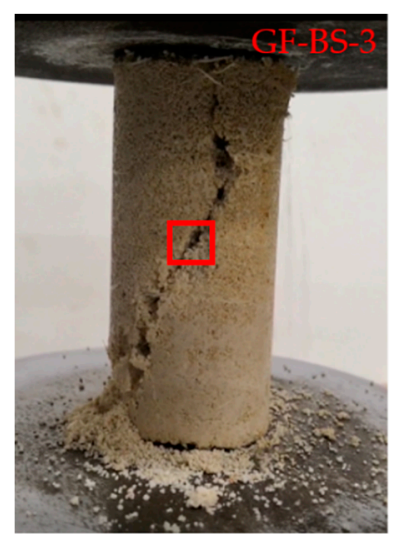

(a)

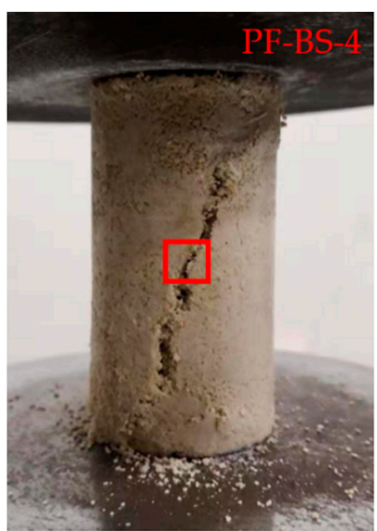

(b)

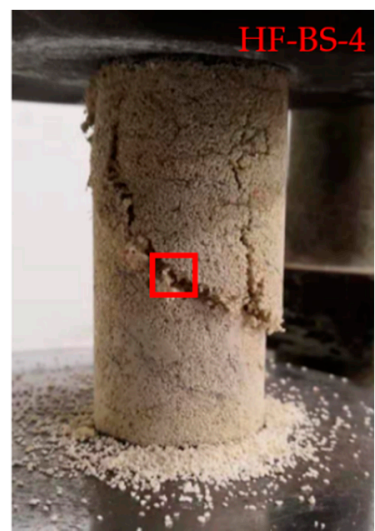

(c)

Figure 12. The specimens' position was used for microscopic analysis: (a) GF-BS-3; (b) PF-BS-4; (c) HF-BS-4.

\subsubsection{Digital LED Microscope Scanning}

Figure 13 below shows digital LED microscope images of sand specimens with different fibers. Figure 13a,b shows that a large amount of calcite had precipitated onto the grain surfaces, grain contacts, fiber surface, and grain-fiber contacts. Specifically, calcite on the fiber surface and grain-fiber contacts led to greater connections in the biocemented sands between fiber and sand grain, termed the "bonding effect", as shown in Figure 13. The bonding effect affected the increase in strength. As shown in Figure 13c, the bonding effect of hemp fiber sand was less than that of glass fiber (Figure 13a) and polyester fiber (Figure 13b). This is one of the reasons why hemp fiber is ineffective in MICP-treated calcareous sand. 


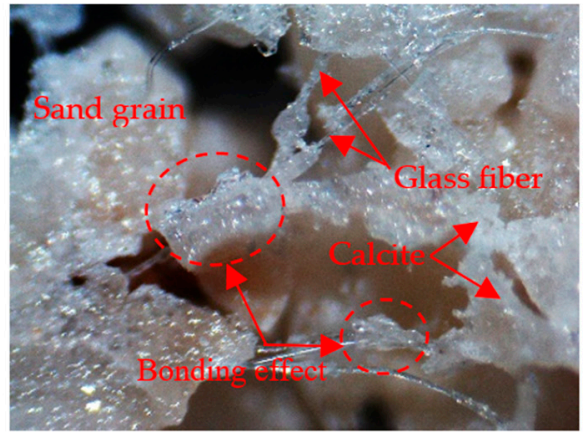

(a)

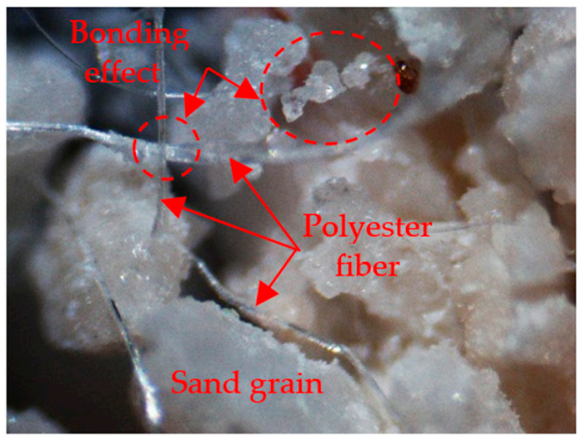

(b)

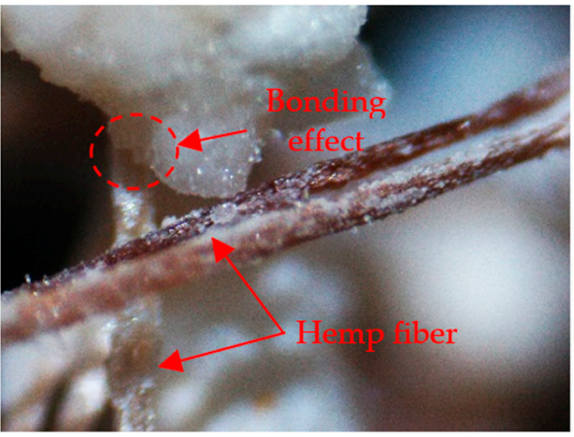

(c)

Figure 13. Digital LED microscope images of sand after microbial-induced calcite precipitation (MICP) reinforcement $(50 \times$ magnification) at (a) $0.2 \%$ glass fiber, (b) $0.25 \%$ polyester, and (c) $0.25 \%$ hemp fiber.

\subsubsection{SEM Scanning}

Figure 14 below shows the SEM images of the biocemented sand mixed with different fibers. As shown in Figure 14, the calcite on the fiber and sand contacts has formed a bonding effect between fiber and sand grains. This is the key factor for the fiber to play a role in biocemented sand. Because of this bonding effect, the ductility and strength of fiber-reinforced biocemented sands were improved. As shown in Figure 14e,f, little calcite had precipitated around the hemp fiber, leading to a poor bonding effect. The unconfined compressive strength of sand mixed with hemp fiber was relatively low, and some contents were even lower than the strength of the BS. Calcium carbonate precipitation of the HF-BS in Table 3 was also less than that of GF-BS and PF-BS. Therefore, it was speculated that this may have been due to hemp fiber being smooth compared to glass and polyester fibers. Hemp fiber had a detrimental effect on the retention of bacterial and cementation solution during grouting. This resulted in reduced calcite precipitation. Figure 14 also shows that after the specimens were damaged, the hemp fibers did not bend noticeably (Figure 14f), while the glass fiber (Figure 14b) and polyester fiber (Figure 14d) did. As a result, the strength of hemp fiber was not fully utilized. Therefore, when the specimens were damaged, the bonding effect between fiber and sand grains was weakened, resulting in reduced strength of the HF-BS.

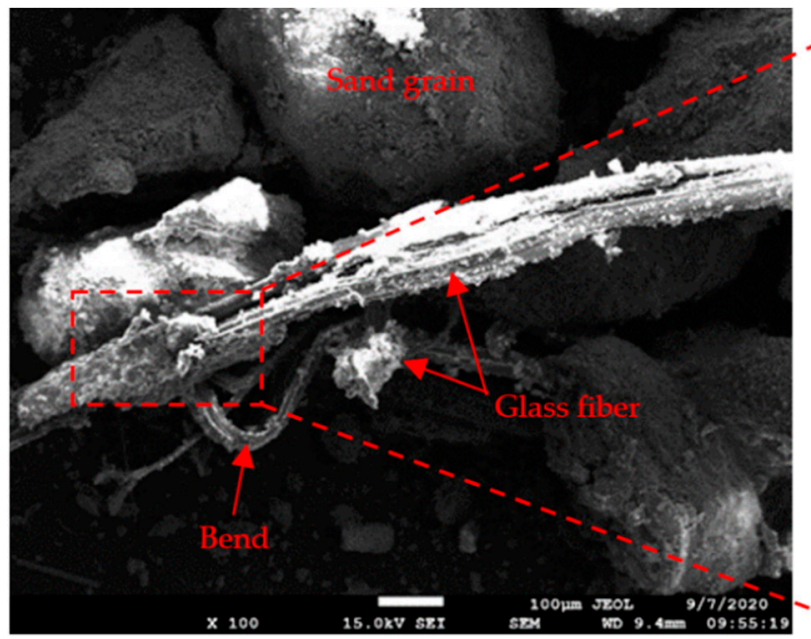

(a)

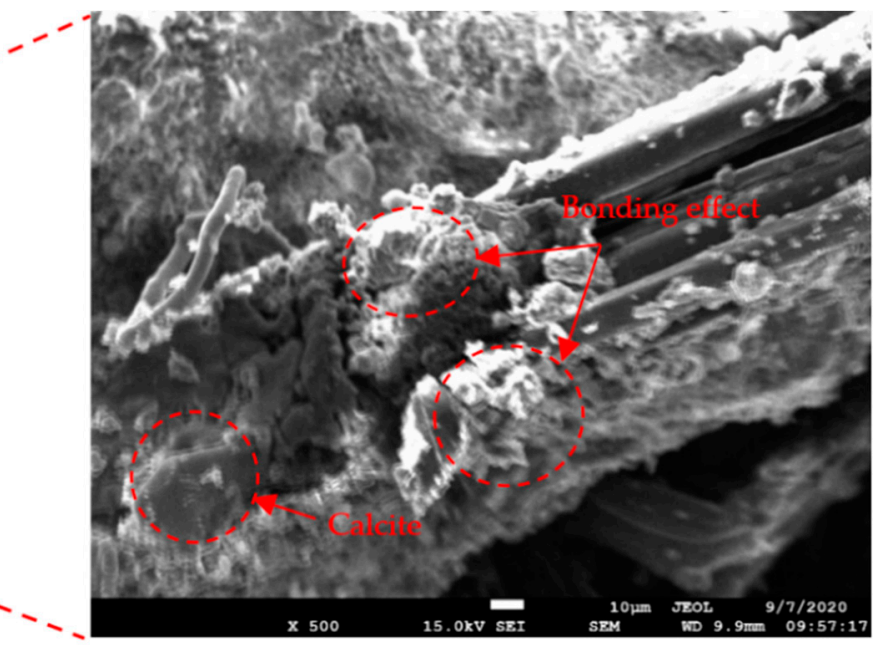

(b)

Figure 14. Cont. 


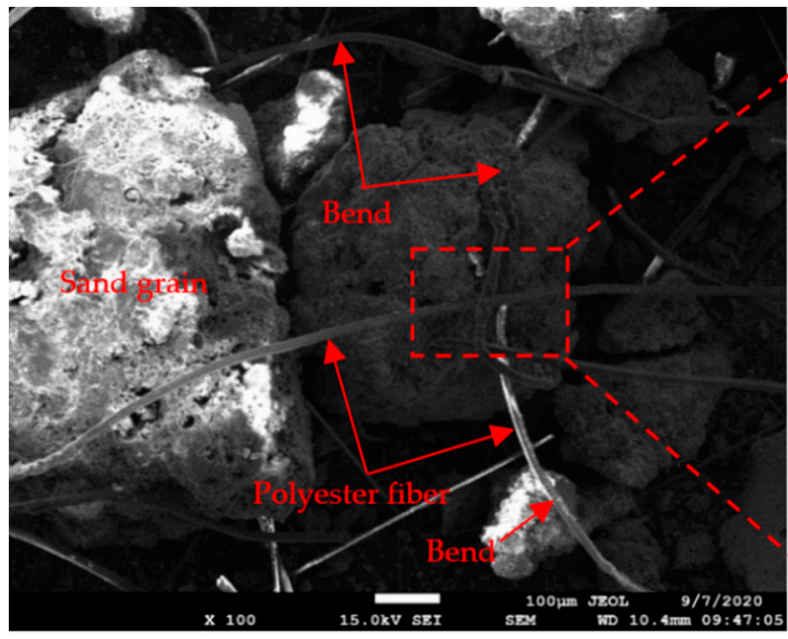

(c)

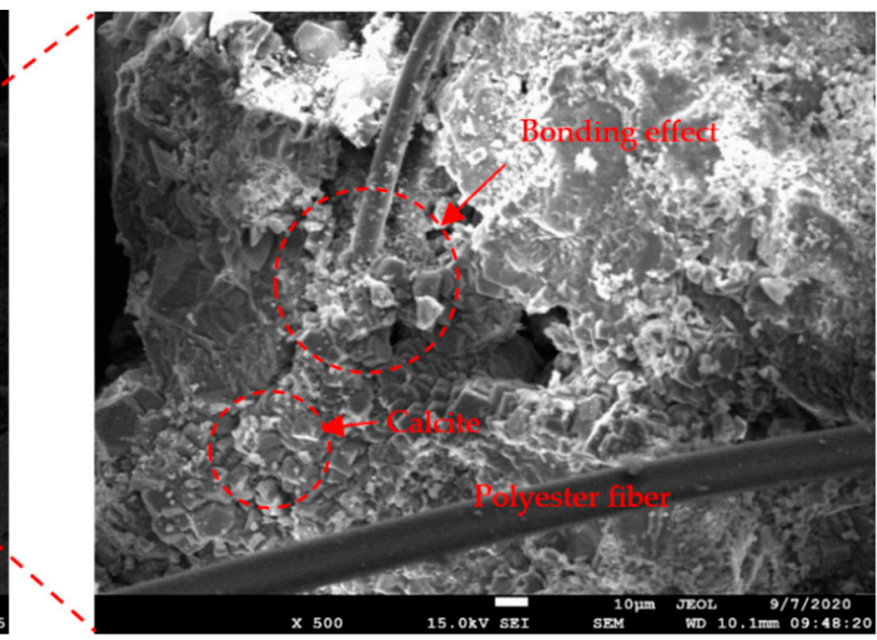

(d)

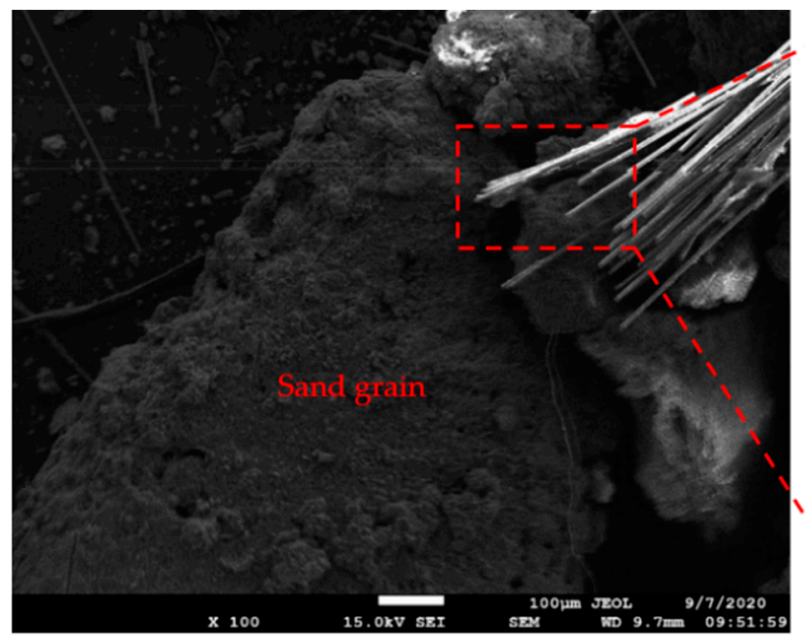

(e)

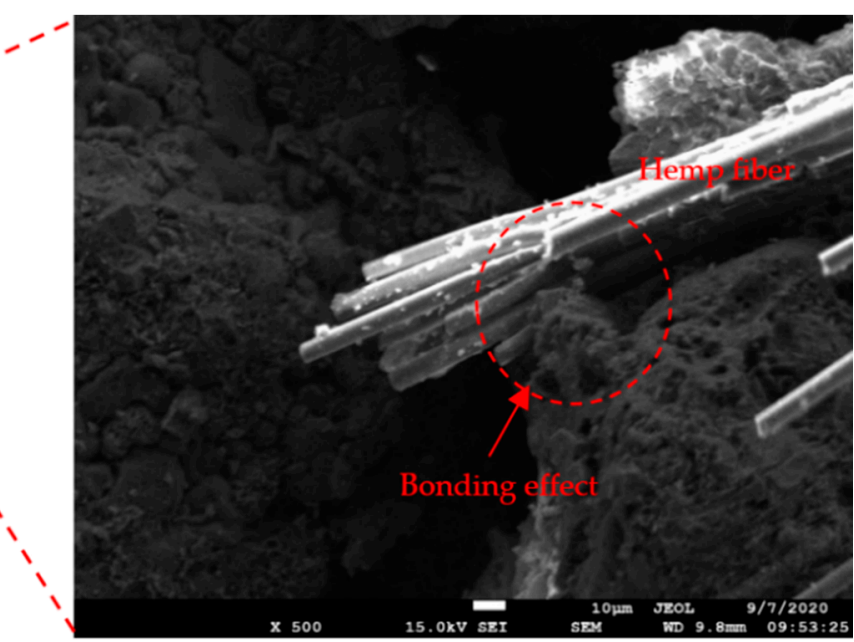

(f)

Figure 14. SEM images of sand after MICP reinforcement of $0.2 \%$ glass fiber at (a) $100 \times$ and (b) $500 \times$ magnification; $0.25 \%$ polyester fiber at (c) $100 \times$ and (d) $500 \times$ magnification, and $0.25 \%$ hemp fiber at (e) $100 \times$ and (f) $500 \times$ magnification.

\subsection{Discussion on the Optimum Fiber Content}

In some previous studies of fiber-reinforced soil, the results of optimum fiber content were also obtained [39-41]. Based on the test results of water absorption and unconfined compressive strength, the optimum content of glass fiber and polyester fiber obtained were $0.20 \%$ and $0.25 \%$, respectively. The optimum content of hemp fiber was within the range of $0.20-0.25 \%$. The reason was that when preparing the sample, the relative density was controlled at $50 \%$ and the height of the sample was controlled at $80 \mathrm{~mm}$, so the pore volume of the sample was consistent. The fibers added would occupy the original pores of the sample and would therefore also occupy the living space of the bacteria. Adding excessive fiber would have compressed the spatial environment of bacterial growth. It could have led to restrained microbial growth and had a negative effect on the precipitation of calcium carbonate. As a result, the strength of the sample would have been reduced. Other similar studies have previously been carried out. Xie [42] added polypropylene fiber to silica sand and microbially reinforced the sand. By unconfined compressive strength and calcium carbonate content tests, Xie concluded that increased fiber content augmented the pore volume occupied by fiber. The growth environment space originally belonging to microorganisms was reduced, which led to further restraining of microbial growth. The increase in fiber content also produced a negative effect on the deposition of calcium 
carbonate. Qiu [43] added carbon fiber to silica and calcareous sand and microbially reinforced the sand. Qiu carried out a series of calcium carbonate content, unconfined compressive strength, and permeability coefficient tests. He concluded that the void in the sand samples was limited, and that the volume of space occupied by fiber increased significantly with higher fiber content. The original growth space of the microorganisms was forced to compress, resulting in a negative effect on the growth of microorganisms. It could also be seen from the calcium carbonate precipitation $\Delta \mathrm{m}$ in Table 3 in this paper that when fiber content increased to a certain value, $\Delta \mathrm{m}$ decreased. This suggested that adding excessive fiber would compress the growth environment space of bacteria and restrain calcium carbonate precipitation.

\section{Conclusions}

Series of water absorption and UCS tests and SEM scanning on three different fiberreinforced biocemented sands were conducted to investigate the effectiveness of three different types of fibers on MICP-treated calcareous sands. The following conclusions can be drawn from the study:

1. For fiber-reinforced biocemented sand, water absorption decreased with increased fiber content. When fiber content rose to a threshold, the water absorption increased as fiber content increased. The minimum water absorption obtained for the GF-BS, PF-BS, and HF-BS was at $0.20 \%, 0.25 \%$, and $0.20 \%$ of fiber content, respectively. This showed a reduction of $11.60 \%, 21.18 \%$, and $7.29 \%$, respectively, in water absorption over the BS. The unconfined compressive strength displayed the opposite trend. The maximum UCS of the GF-BS, PF-BS, and HF-BS obtained was at $0.20 \%, 0.25 \%$, and $0.25 \%$ of fiber content, respectively. The maximum strengths were $1.668 \mathrm{MPa}, 2.159 \mathrm{MPa}$, and $1.429 \mathrm{MPa}$. This showed an increase of $24.20 \%, 60.76 \%$, and $6.40 \%$, respectively, in strength over the BS. On the whole, with the increase in water absorption, the UCS of the sample decreased. This indicated that the pores on the surface of the sample had a negative effect on the strength of the sample.

2. For the PF-BS, when the polyester fiber content was $0.2 \%$ to $0.4 \%$, the ductility of the sample could be increased. For the HF-BS, only when the stress value of the sample decreased to a low level, did the decreasing trend of the stress and strain become slow. This indicated that the hemp fiber was unable to play an immediate role when the sample was destroyed. For the modulus of elasticity of these three fibers, the PF-BS was the highest, followed by the GF-BS and HF-BS. This indicated that the stress of PF-BS was the highest under the same strain conditions. In other words, the PF-BS achieved the strongest stiffness.

3. The failure patterns of different fiber-reinforced biocemented sands indicated that the glass fiber and polyester fiber were more effective in improving the properties of the biocemented sand. The failure form of the samples mixed with these two types of fibers was damaged by splitting failure at the maximum unconfined compressive strength, while the hemp fiber sample was damaged by shear failure. The BS was damaged by partial failure. Therefore, the fiber-reinforced biocemented sands displayed better integrity after damage.

4. The digital LED microscope and SEM scanning images demonstrated that the calcite on the fiber and sand contacts formed a bonding effect between fiber and sand grains, which was identified as the key factor for fiber to play a role in biocemented sands. In contrast, in the case of hemp fiber, little calcite precipitation was noted around it, leading to a poor bonding effect. It was speculated that hemp fiber was smooth compared with glass and polyester fiber, which had a detrimental effect on the retention of bacterial and cementation solution during grouting, so the strength of the HF-BS was reduced.

Overall, the optimum contents of glass fiber and polyester fiber were $0.20 \%$ and $0.25 \%$. The optimum content of hemp fiber was within the range of $0.20-0.25 \%$. It could be seen from the water absorption and unconfined compressive strength tests that the polyester 
fiber was the most effective, followed by glass fiber, while hemp fiber proved to be the least effective. We therefore suggest that polyester fiber, which is a typical synthetic fiber, should be used to strengthen calcareous sand for optimal results. During the preparation of samples, the fibers easily formed into clumps, resulting in decreased uniformity of distribution of the fibers in the soil sample. Achieving a more even fiber distribution in the sand column was thus shown to greatly improve calcium carbonate distribution and soil sample strength improvement. These findings merit further investigation, analysis, and discussion in future research.

Author Contributions: Conceptualization, J.Z. and Q.P.; methodology, H.T. and J.Y.; software, Y.S. and J.Y.; validation, J.Y., Y.S. and J.L.; formal analysis, Y.S. and J.Z.; investigation, J.Z. and J.L.; resources, J.Y. and H.T.; data curation, J.Z.; writing—original draft preparation, J.Z. and Q.P.; writingreview and editing, J.Z.; visualization, J.Y. and J.Z.; supervision, H.T. and Y.S.; project administration, H.T. and J.Y.; funding acquisition, H.T. and J.Y. All authors have read and agreed to the published version of the manuscript.

Funding: This study is supported by the National Natural Science Foundation of China (No. 51908151, No. 51778159), the Chinese Postdoctoral Science Foundation (No. 2020M682652), the Guangzhou Science and Technology Program key projects (No. 201804010250), and the Guangzhou University Postgraduate Innovation Ability Training Funding Program (No. 2019GDJC-M31).

Institutional Review Board Statement: Not applicable.

Informed Consent Statement: Not applicable.

Data Availability Statement: The data presented in this study are available in J.Z., H.T., Y.S., J.Y., Q.P., J.L. Effects of Different Types of Fibers on the Physical and Mechanical Properties of MICP-Treated Calcareous Sand.

Acknowledgments: The authors would like to thank the technicians in the Geotechnical laboratories of Guangzhou University, Y.S., Q.P. and J.Z., for their technical support and assistance in experimental activities. Furthermore, we would like to thank H.T., J.Y. and Y.S. for their help and careful guidance during the research process.

Conflicts of Interest: The authors declare no conflict of interest.

\section{References}

1. Wang, X.-Z.; Wang, X.; Chen, J.-W.; Wang, R.; Hu, M.-J.; Meng, Q.-S. Experimental study on permeability characteristics of calcareous soil. Bull. Int. Assoc. Eng. Geol. 2017, 77, 1753-1762. [CrossRef]

2. Jafarian, Y.; Javdanian, H. Dynamic Properties of Calcareous Sand from the Persian Gulf in Comparison with Siliceous Sands Database. Int. J. Civ. Eng. 2019, 18, 245-249. [CrossRef]

3. Wang, S.; Lei, X.-W.; Meng, Q.; Xu, J.-L.; Xie, L.-F.; Li, Y.-J. Influence of Particle Shape on the Density and Compressive Performance of Calcareous Sand. KSCE J. Civ. Eng. 2019, 24, 49-62. [CrossRef]

4. Umar, M.; Kassim, K.A.; Chiet, K.T.P. Biological process of soil improvement in civil engineering: A review. J. Rock Mech. Geotech. Eng. 2016, 8, 767-774. [CrossRef]

5. Phillips, A.J.; Gerlach, R.; Lauchnor, E.; Mitchell, A.C.; Cunningham, A.B.; Spangler, L. Engineered applications of ureolytic biomineralization: A review. Biofouling 2013, 29, 715-733. [CrossRef] [PubMed]

6. Whiffin, V.S. Microbial CaCO3 Precipitation for the Production of Biocement. Ph.D. Thesis, Murdoch University, Perth, WA, Australia, 2004.

7. Dejong, J.T.; Soga, K.; Kavazanjian, E.; Burns, S.E.; Van Paassen, L.A.; Al Qabany, A.; Aydilek, A.; Bang, S.S.; Burbank, M.; Caslake, L.F.; et al. Biogeochemical processes and geotechnical ap-plications: Progress, opportunities and challenges. Geotechnique 2013, 63, 287-301. [CrossRef]

8. DeJong, J.T.; Fritzges, M.B.; Nüsslein, K. Microbially Induced Cementation to Control Sand Response to Undrained Shear. J. Geotech. Geoenviron. Eng. 2006, 132, 1381-1392. [CrossRef]

9. Whiffin, V.S.; Van Paassen, L.A.; Harkes, M.P. Microbial Carbonate Precipitation as a Soil Improvement Technique. Geomicrobiol. J. 2007, 24, 417-423. [CrossRef]

10. van Paassen, L.A.; Ghose, R.; van der Linden, T.J.M.; van der Star, W.R.L.; van Loosdrecht, M.C.M. Quantifying Biome-diated Ground Improvement by Ureolysis: Large-Scale Biogrout Experiment. J. Geotech. Geoenviron. Eng. 2010, 136, 1721-1728. [CrossRef]

11. Van Wijngaarden, W.K.; Vermolen, F.; Van Meurs, G.A.M.; Vuik, C. Modelling Biogrout: A New Ground Improvement Method Based on Microbial-Induced Carbonate Precipitation. Transp. Porous Media 2010, 87, 397-420. [CrossRef] 
12. Montoya, B.M.; DeJong, J.T. Stress-Strain Behavior of Sands Cemented by Microbially Induced Calcite Precipitation. J. Geotech. Geoenviron. Eng. 2015, 141, 04015019. [CrossRef]

13. Chu, J.; Ivanov, V.; Stabnikov, V.; Li, B. Microbial method for construction of an aquaculture pond in sand. Bio-and Chemo-Mech. Process. Geotech. Eng. 2014, 63, 215-219. [CrossRef]

14. Cuthbert, M.O.; McMillan, L.A.; Handley-Sidhu, S.; Riley, M.S.; Tobler, D.J.; Phoenix, V.R. A Field and Modeling Study of Fractured Rock Permeability Reduction Using Microbially Induced Calcite Precipitation. Environ. Sci. Technol. 2013, 47, 13637-13643. [CrossRef] [PubMed]

15. Phillips, A.J.; Cunningham, A.B.; Gerlach, R.; Hiebert, R.; Hwang, C.; Lomans, B.P.; Westrich, J.; Mantilla, C.; Kirksey, J.; Esposito, R.; et al. Fracture Sealing with Microbially-Induced Calcium Carbonate Precipitation: A Field Study. Environ. Sci. Technol. 2016, 50, 4111-4117. [CrossRef] [PubMed]

16. Minto, J.M.; Lunn, R.J.; El Mountassir, G. Development of a Reactive Transport Model for Field-Scale Simulation of Microbially Induced Carbonate Precipitation. Water Resour. Res. 2019, 55, 7229-7245. [CrossRef]

17. Montoya, B.M.; Dejong, J.T.; Boulanger, R.W.; Wilson, D.W.; Gerhard, R.; Chou, J.-C. In Liquefaction Mitigation Using Microbial Induced Calcite Precipitation. GeoCongress 2012, 1918-1927. [CrossRef]

18. Montoya, B.M.; DeJong, J.T.; Boulanger, R.W. Dynamic response of liquefiable sand improved by microbial-induced calcite precipitation. Bio- Chemo-Mech. Proc. Geotech. Eng. 2014, 63, 125-135. [CrossRef]

19. Xiao, P.; Liu, H.; Xiao, Y.; Stuedlein, A.W.; Evans, T.M. Liquefaction resistance of bio-cemented calcareous sand. Soil Dyn. Earthq. Eng. 2018, 107, 9-19. [CrossRef]

20. Wang, J.; Ersan, Y.C.; Boon, N.; De Belie, N. Application of microorganisms in concrete: A promising sustainable strategy to improve concrete durability. Appl. Microbiol. Biotechnol. 2016, 100, 2993-3007. [CrossRef]

21. Zhang, Z.; Weng, Y.; Ding, Y.; Qian, S. Use of Genetically Modified Bacteria to Repair Cracks in Concrete. Materials 2019, 12, 3912. [CrossRef]

22. Chen, H.-J.; Peng, C.-F.; Tang, C.-W.; Chen, Y.-T. Self-Healing Concrete by Biological Substrate. Materials 2019, 12, 4099. [CrossRef] [PubMed]

23. Choi, S.-G.; Wang, K.; Chu, J. Properties of biocemented, fiber reinforced sand. Constr. Build. Mater. 2016, 120, 623-629. [CrossRef]

24. Choi, S.-G.; Hoang, T.; Alleman, E.J.; Chu, J. Splitting Tensile Strength of Fiber-Reinforced and Biocemented Sand. J. Mater. Civ. Eng. 2019, 31, 06019007. [CrossRef]

25. Xiao, Y.; He, X.; Evans, T.M.; Stuedlein, A.W.; Liu, H. Unconfined Compressive and Splitting Tensile Strength of Basalt FiberReinforced Biocemented Sand. J. Geotech. Geoenviron. Eng. 2019, 145, 04019048. [CrossRef]

26. Imran, A.; Gowthaman, S.; Nakashima, K.; Kawasaki, S. The Influence of the Addition of Plant-Based Natural Fibers (Jute) on Biocemented Sand Using MICP Method. Materials 2020, 13, 4198. [CrossRef]

27. Benessalah, I.; Arab, A.; Villard, P.; Sadek, M.; Kadri, A. Laboratory Study on Shear Strength Behaviour of Reinforced Sandy Soil: Effect of Glass-Fibre Content and Other Parameters. Arab. J. Sci. Eng. 2015, 41, 1343-1353. [CrossRef]

28. Orakoglu, M.E.; Liu, J.; Niu, F. Dynamic behavior of fiber-reinforced soil under freeze-thaw cycles. Soil Dyn. Earthq. Eng. 2017, 101, 269-284. [CrossRef]

29. Wang, L.; He, C. Thermal and wear behavior of three inorganic fiber-reinforced wood-plastic composites in simulated soil aging conditions. Polym. Test. 2019, 80, 106129. [CrossRef]

30. Chaduvula, U.; Viswanadham, B.; Kodikara, J. A study on desiccation cracking behavior of polyester fiber-reinforced expansive clay. Appl. Clay Sci. 2017, 142, 163-172. [CrossRef]

31. Lv, X.; Zhou, H. Shear Characteristics of Cement-Stabilized Sand Reinforced with Waste Polyester Fiber Fabric Blocks. Adv. Mater. Sci. Eng. 2019, 2019, 3758413. [CrossRef]

32. Diab, A.A.; Najjar, S.S.; Sadek, S.; Taha, H.; Jaffal, H.; Alahmad, M. Effect of compaction method on the undrained strength of fiber-reinforced clay. Soils Found. 2018, 58, 462-480. [CrossRef]

33. Ammar, A.; Najjar, S.S.; Sadek, S. Mechanics of the Interface Interaction between Hemp Fibers and Compacted Clay. Int. J. Géoméch. 2019, 19, 04019015. [CrossRef]

34. Soon, N.W.; Lee, L.M.; Khun, T.C.; Ling, H.S. Factors Affecting Improvement in Engineering Properties of Residual Soil through Microbial-Induced Calcite Precipitation. J. Geotech. Geoenviron. Eng. 2014, 140, 04014006. [CrossRef]

35. Ahmad, F.; Mujah, D.; Hazarika, H.; Safari, A. Assessing the potential reuse of recycled glass fibre in problematic soil appli-cations. J. Clean. Prod. 2012, 35, 102-107. [CrossRef]

36. Xiao, P.; Liu, H.; Stuedlein, A.W.; Evans, T.M.; Xiao, Y. Effect of relative density and biocementation on cyclic response of calcareous sand. Can. Geotech. J. 2019, 56, 1849-1862. [CrossRef]

37. Xiao, Y.; Zhao, C.; Sun, Y.; Wang, S.; Wu, H.; Chen, H.; Liu, H. Compression behavior of MICP-treated sand with various gradations. Acta Geotech. 2020, 1-10. [CrossRef]

38. Manzur, T.; Rahman, F.; Afroz, S.; Huq, R.S.; Efaz, I.H. Potential of a Microbiologically Induced Calcite Precipitation Process for Durability Enhancement of Masonry Aggregate Concrete. J. Mater. Civ. Eng. 2017, 29, 04016290. [CrossRef]

39. Prabakar, J.; Sridhar, R. Effect of random inclusion of sisal fibre on strength behaviour of soil. Constr. Build. Mater. 2002, 16, 123-131. [CrossRef]

40. Akbulut, S.; Arasan, S.; Kalkan, E. Modification of clayey soils using scrap tire rubber and synthetic fibers. Appl. Clay Sci. 2007, 38, 23-32. [CrossRef] 
41. Fang, X.; Yang, Y.; Chen, Z.; Liu, H.; Xiao, Y.; Shen, C. Influence of Fiber Content and Length on Engineering Properties of MICP-Treated Coral Sand. Geomicrobiol. J. 2020, 37, 582-594. [CrossRef]

42. Xie, Y.; Tang, C.; Yin, L.; Lv, C.; Jiang, N.; Shi, B. Mechanical behavior of microbial-induced calcite precipitation (MICP)-treated soil with fiber reinforcement. Chi. J. Geotech. Eng. 2019, 41, 675-682. [CrossRef]

43. Qiu, R.; Tong, H.; Gu, M.; Yuan, J. Strength and Micromechanism Analysis of Microbial Solidified Sand with Carbon Fiber. Adv. Civ. Eng. 2020, 2020, 1-10. [CrossRef] 